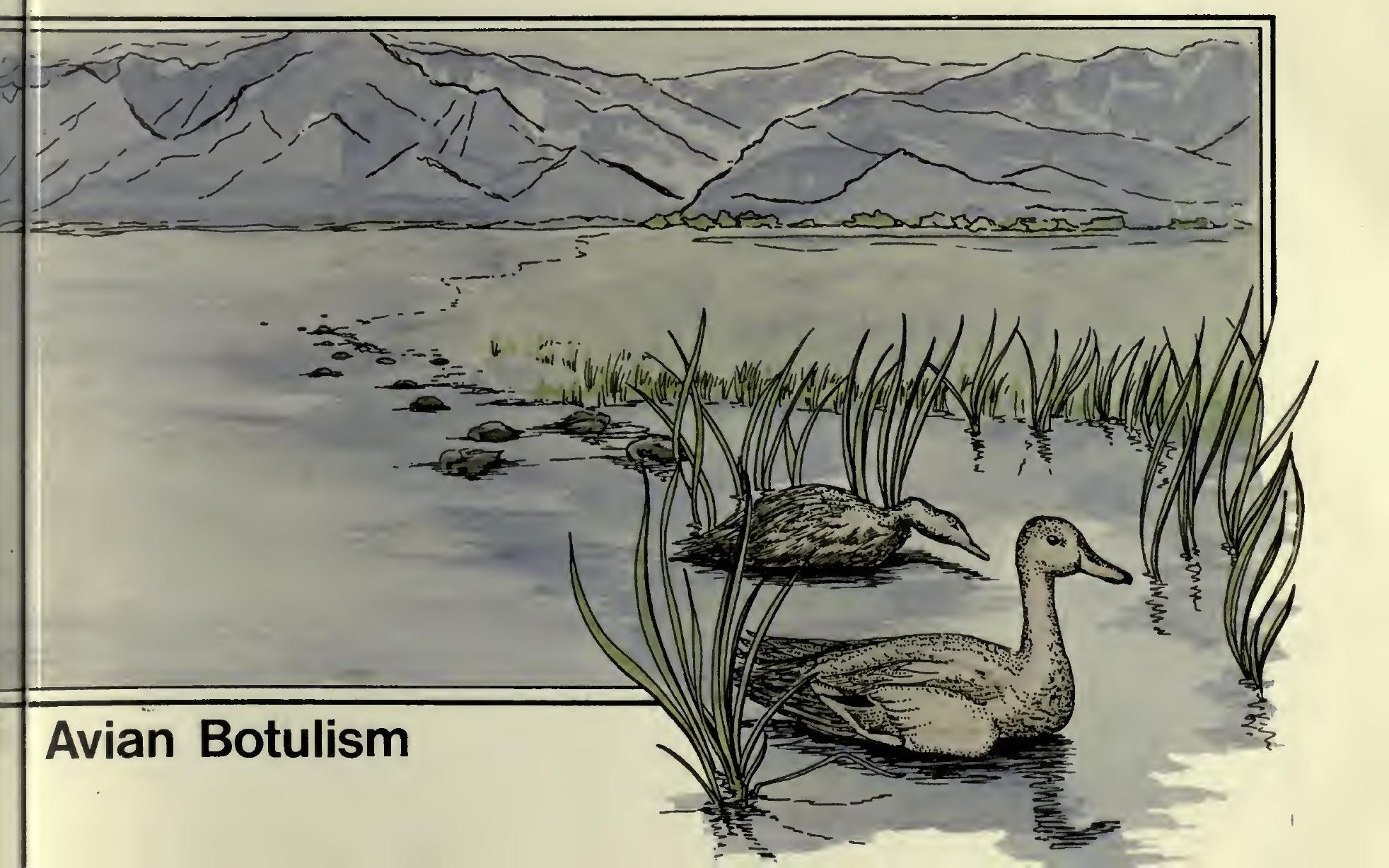




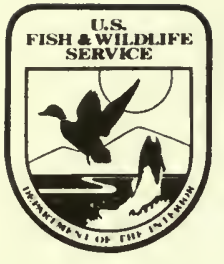

This publication was funded jointly by the National Park Service and the Fish and Wildlife Service, U.S. Department of Interior.

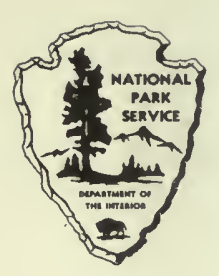

Authors: Milton Friend, Louis N. Locke and James J. Kennelly, National Wildlife Health Laboratory, Madison, WI.

Technical Writer: Diana H. Cross, Office of Information Transfer, Ft. Collins, CO.

Cover and Illustrations: Randy S. Kampen, Madison, WI.

Photographs courtesy the National Wildlife Health Laboratory 


\section{WHAT IS AVIAN BOTULISM?}

Avian botulism, or Western duck sickness, is one of the three most important disease problems of wild migratory birds. Each year, many birds are paralyzed or die after exposure to a toxin produced by the botulinum bacterium. Two of the seven toxin types that have been identified commonly cause mortality in wild birds; one of these, type $\mathrm{C}$, is most often associated with dieoffs of ducks, while type E primarily affects gulls and loons.

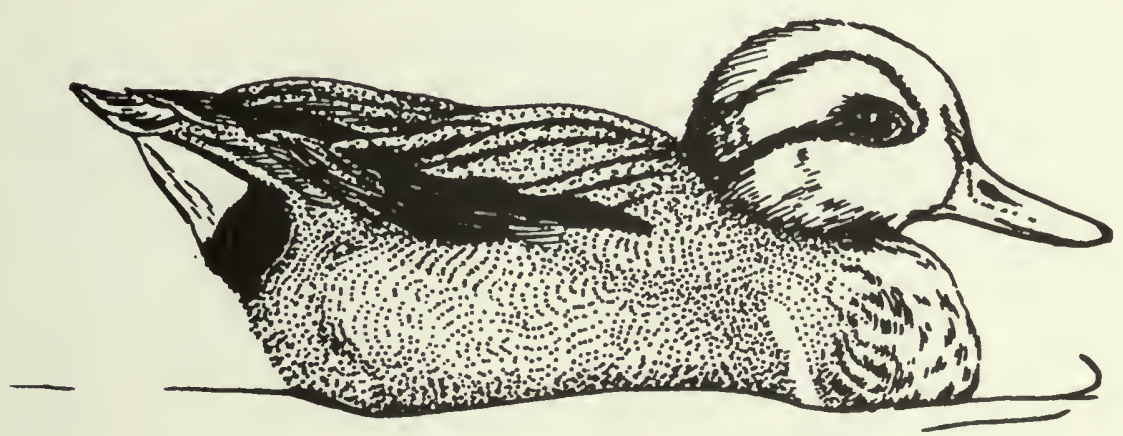




\section{HOW SERIOUS IS IT?}

Losses vary from year to year and from species to species. A few hundred birds may die one year at a specific location, with tens of thousands dying the following year at the same site. More than a million deaths from avian botulism have been reported in localized outbreaks in a single year. Outbreaks causing losses of 50,000 or more birds are fairly common.

\section{Initial Outbreaks of Type C Botulism in Wild Waterfowl}

Americas

United States

Canada

Uruguay

Mexico

Australia-Asia

Australia

New Zealand

Japan

\section{Europe-Africa}

1910

1913

1921

1976

1934

1972

1973
1967

1969

1970

1971

1971

1973

1973

Spain

1956 


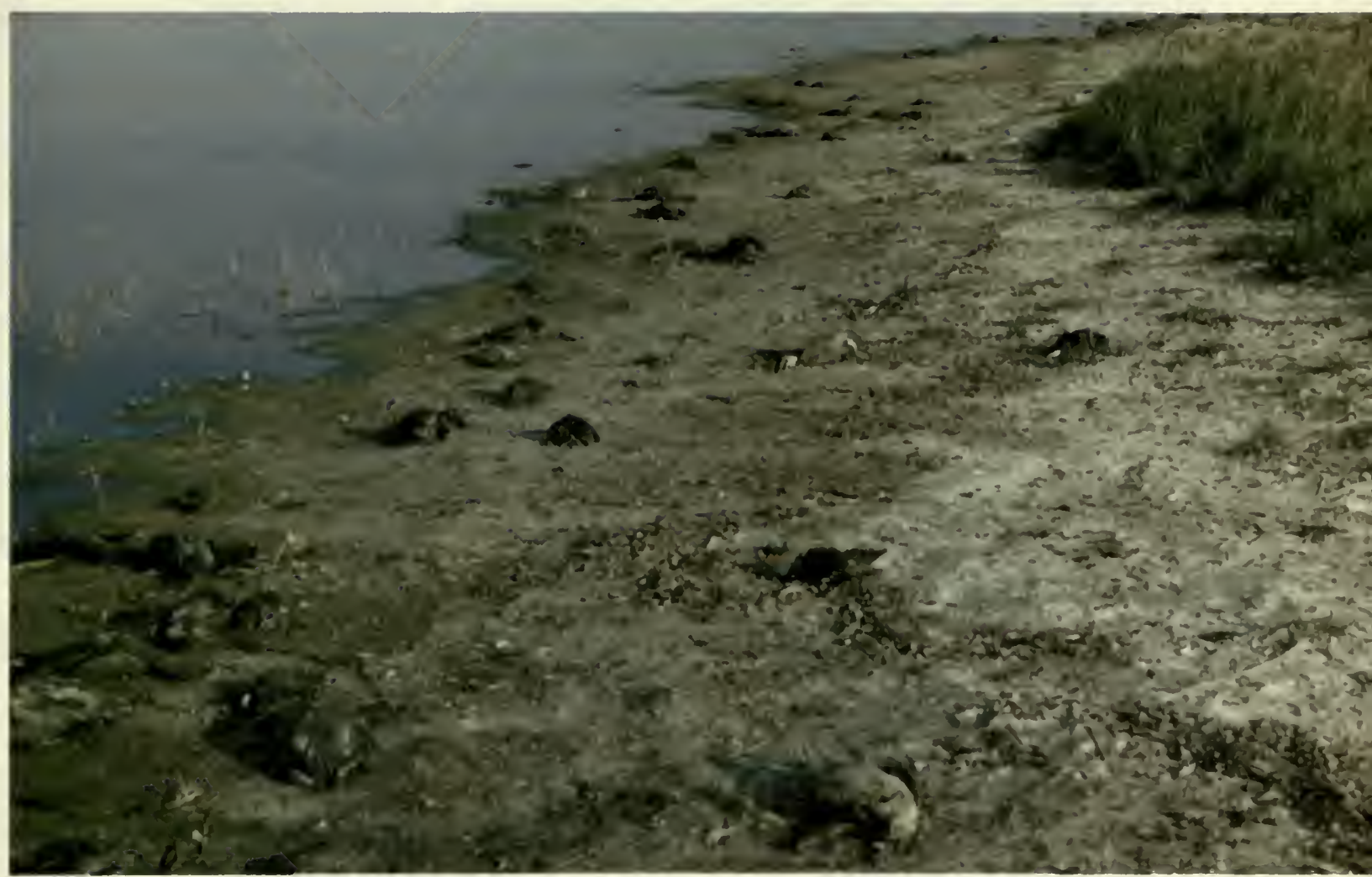

A Montana marsh experiences an outbreak of type $\mathrm{C}$ avian botulism. 


\section{WHERE DOES IT OCCUR?}

Avian botulism has been reported from every continent except Antarctica. Outbreaks of avian botulism have occurred in North America since the beginning of the century, if not earlier. Most occurrences have been reported within the past 20 years. Most type C outbreaks in the United States occur west of the Mississippi River; however, outbreaks have occurred from coast to coast and border to border. Type E outbreaks in birds are less frequent and have been confined to the Great Lakes region.

\section{Major Waterfowl Botulism Outbreaks in the U.S.}

Year

1910

1925

1929

1941

1952

1978

1979

1980
Estimated Loss

"Millions"

100,000

$100-300,000$

250,000

4-5 Million

50,000

100,000

110,000

\section{Location}

Utah \& California

Lake Malheur, Oregon

Great Salt Lake, Utah

Tulare Basin, California

Western United States

Montana

Montana

Great Salt Lake, Utah 


\section{Frequency of Type C Botulism in Waterfowl}

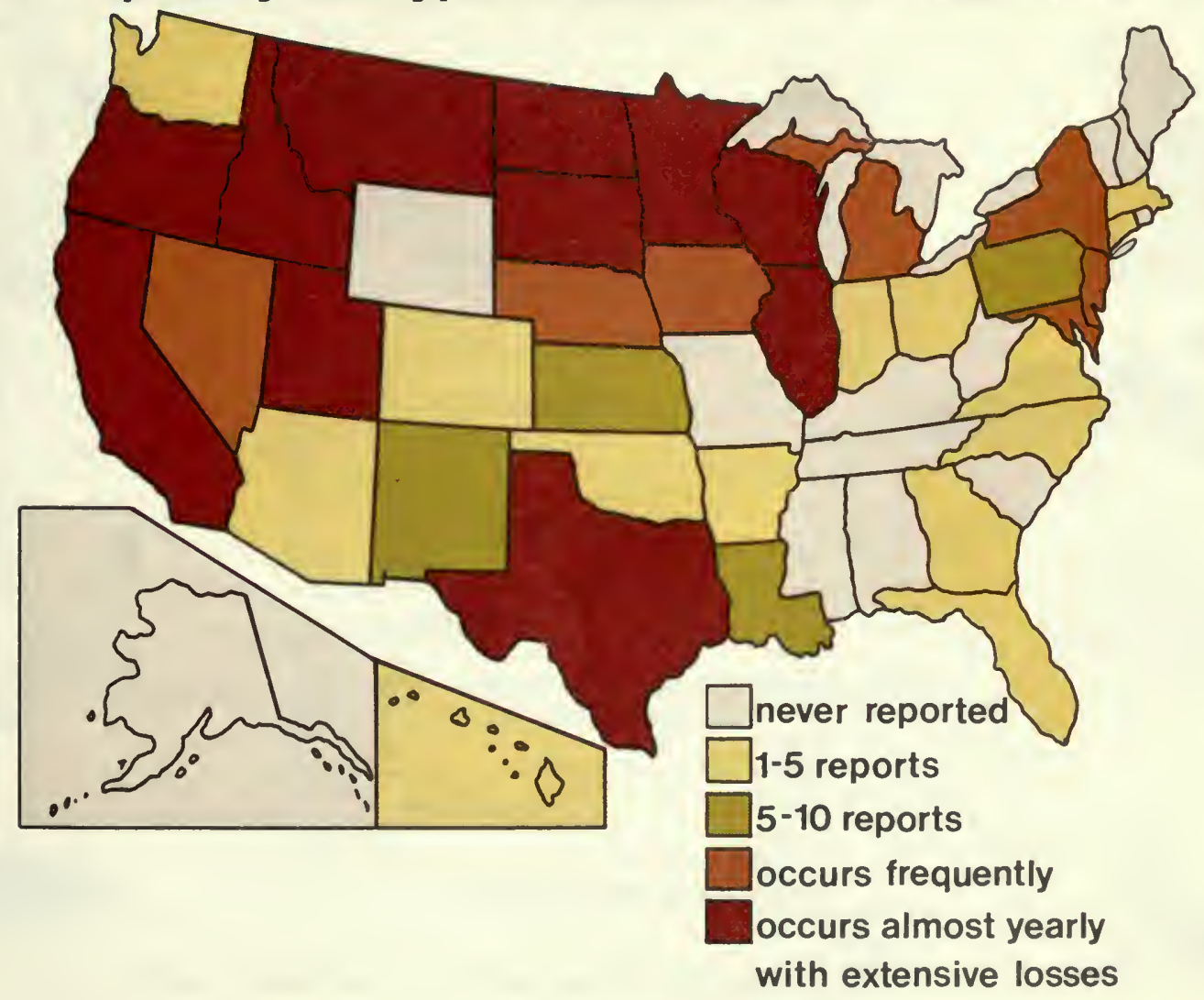


Frequency of Botulism in Major Groups of Wild Birds

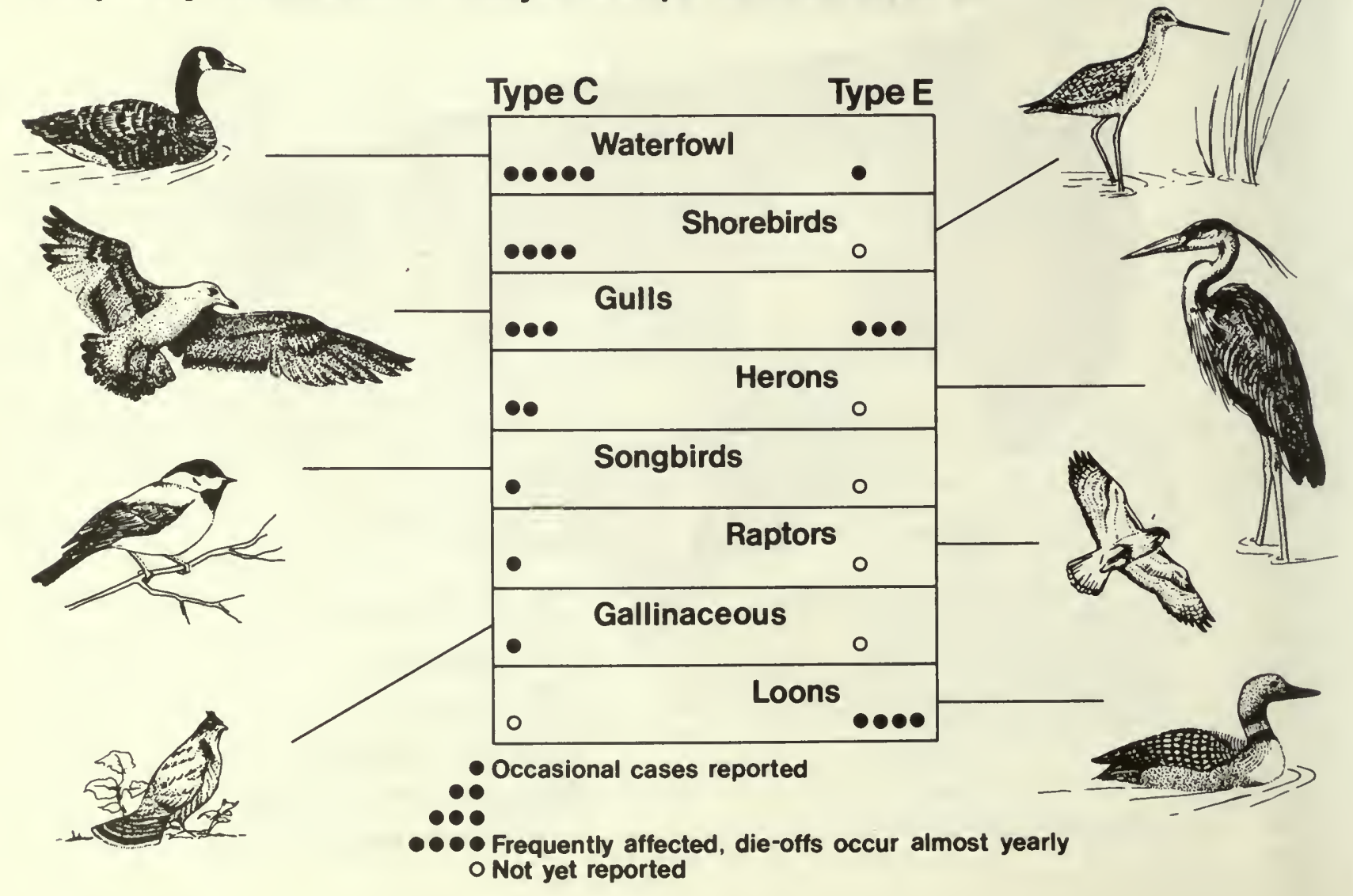


Frequency of Botulism in Captive Birds

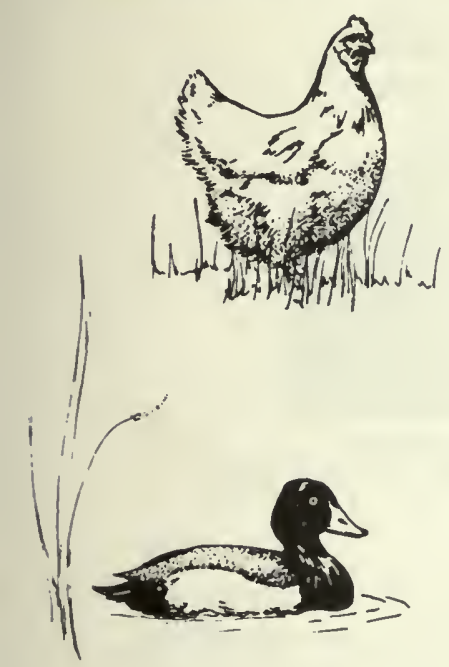

N.America

\begin{tabular}{|ll|}
\hline \multicolumn{3}{|l|}{ Pheasants } \\
\hline \multicolumn{3}{|l|}{ Domestic chickens } \\
\hline & Songbirds \\
\hline & Waterfowl \\
\hline
\end{tabular}

- Occasional cases reported

- Die-offs frequently occur each year

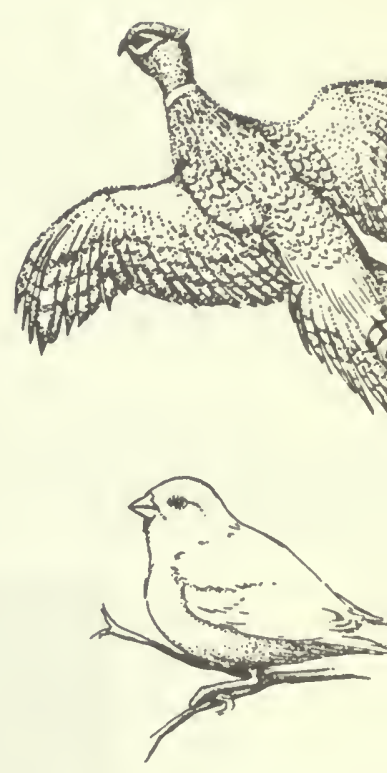




\section{WHAT SPECIES ARE AFFECTED?}

A wide variety of birds and some species of mammals are susceptible to type $\mathrm{C}$ botulism poisoning. Among wild birds, waterfowl (ducks, geese, and swans) and shorebirds are most often affected. Waterfowl, pheasants, and ranch mink are most often involved in captive situations. Vultures, on the other hand, are known to be highly resistant to type $\mathrm{C}$ toxin.

\section{ARE HUMANS AND PETS SUSCEPTIBLE?}

A few cases have been reported in dogs; however, humans, dogs and cats are generally considered resistant to type $\mathrm{C}$ avian botulism. Proper cooking will destroy any toxin present in food items.

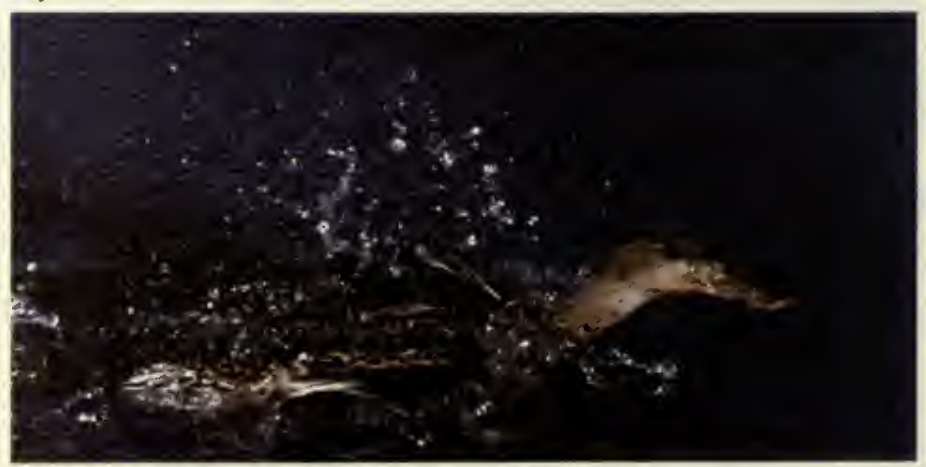

An intoxicated bird propels itself across the water with its wings. 


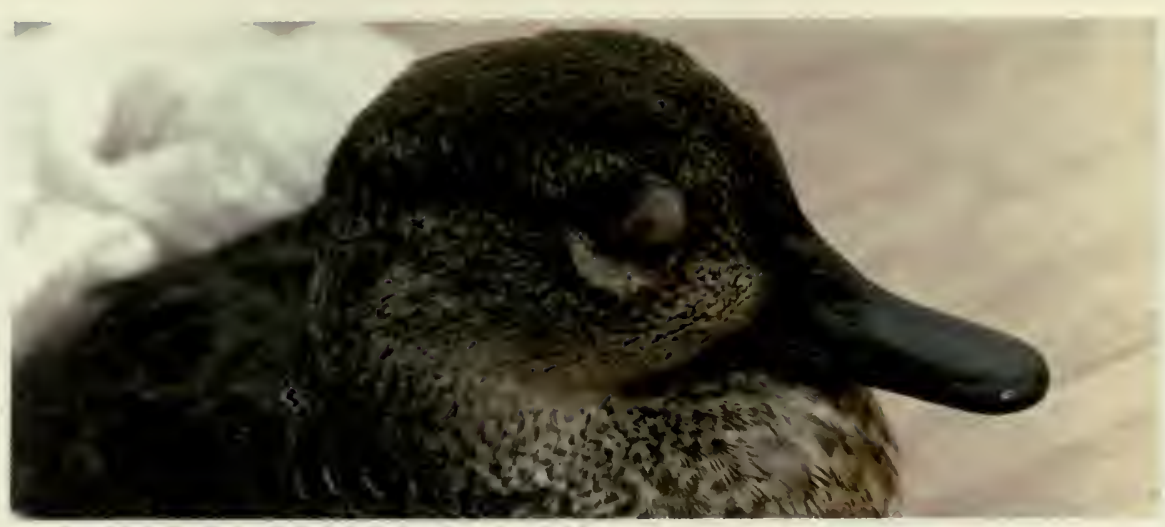

A paralyzed inner eyelid is one sign of avian botulism.

\section{HOW CAN BOTULISM POISONING BE RECOGNIZED?}

Avian botulism affects the nervous system, causing muscle paralysis. Depending on how ar the disease has progressed, various levels of paralysis will be observed. An early sign in irds is the inability to fly. Once the ability to fly is lost and leg muscles become paralyzed, ucks suffering from botulism often propel themselves across the water and mud flats with heir wings. This sequence of signs is in contrast to that of lead-poisoned birds, which have ifficulty flying but remain able to walk and run.

Paralysis of the inner eyelid and neck muscles follows. These are the two most easily ecognizable signs associated with avian botulism. The inability of the bird to hold its head rect is the reason this disease is called limberneck. Frequently, birds drown once they reach his stage in the disease. Those that do not drown will eventually die from respiratory ailure as paralysis spreads. 


\section{HOW IS A DIAGNOSIS MADE?}

A presumptive diagnosis is often made based on a combination of the paralysis observed in sick birds, and the absence of obvious gross lesions of disease in internal organs and tissues of sick or dead birds. However, this initial diagnosis must be confirmed by the mouse-protection test to separate avian botulism from other types of poisoning.

In this test, blood is collected from a sick or freshly dead bird and the serum fraction is injected into two groups of laboratory mice. One of the groups was previously given antitoxin. If botulinum toxin is present in the blood, unprotected mice will become sick or die, while the group receiving antitoxin will survive.

\section{WHAT CAUSES AVIAN BOTULISM EPIDEMICS?}

\section{Environmental Conditions}

Avian botulism is most likely to occur in the presence of high air temperatures, fluctuating water levels, and a suitable medium for bacterial growth, such as vertebrate and invertebrate carcasses near bird concentrations. The botulism bacteria are widely distributed in organic soils. They persist, in nature, in a spore form that is resistant to adverse environmental conditions such as drying and low air temperatures. Development of these spores requires complete absence of oxygen, temperatures ranging from 60 to $97^{\circ} \mathrm{F}$, a source of animal protein, and a $\mathrm{pH}$ ranging from 5.7 to 8.0. 


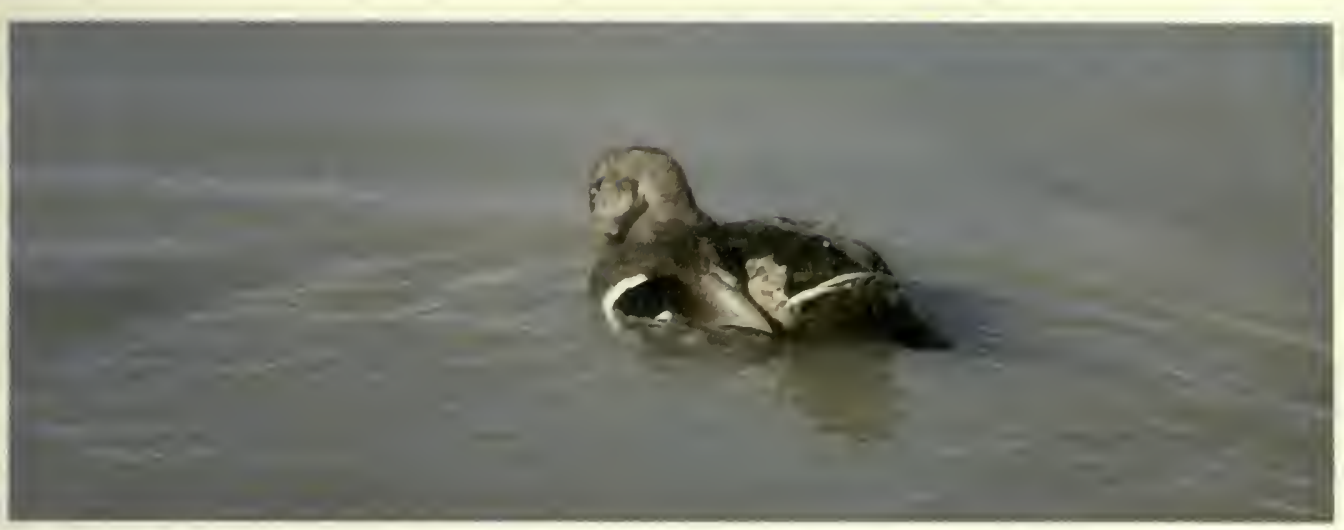

Limberneck occurs at an advanced stage of botulism poisoning.

\section{The Botulism Cycle}

Favorable environmental conditions occur in the tissues of decaying animal and insect carcasses. The decomposition process uses up all available oxygen in the carcass, creating anaerobic conditions. Bacterial spores ingested during the life of the animal germinate after death. As the bacteria multiply and die, toxin is released.

Outbreaks of avian botulism occur when the toxin is taken in by birds. The die-off may begin as birds feed directly on invertebrate carcasses that contain the toxin, or as a result of feeding on live maggots of flesh-flies and blowflies. Flies lay their eggs on dead vertebrates, and the resulting maggots store botulinal toxin in their bodies as they consume the carcass. More than 5,000 maggots can be produced by a single bird carcass; consumption of just two to five toxin-bearing maggots is often enough to kill a duck! 


\section{HOW IS A DIAGNOSIS MADE?}

A presumptive diagnosis is often made based on a combination of the paralysis observed in sick birds, and the absence of obvious gross lesions of disease in internal organs and tissues of sick or dead birds. However, this initial diagnosis must be confirmed by the mouse-protection test to separate avian botulism from other types of poisoning.

In this test, blood is collected from a sick or freshly dead bird and the serum fraction is injected into two groups of laboratory mice. One of the groups was previously given antitoxin. If botulinum toxin is present in the blood, unprotected mice will become sick or die, while the group receiving antitoxin will survive.

\section{WHAT CAUSES AVIAN BOTULISM EPIDEMICS?}

\section{Environmental Conditions}

Avian botulism is most likely to occur in the presence of high air temperatures, fluctuating water levels, and a suitable medium for bacterial growth, such as vertebrate and invertebrate carcasses near bird concentrations. The botulism bacteria are widely distributed in organic soils. They persist, in nature, in a spore form that is resistant to adverse environmental conditions such as drying and low air temperatures. Development of these spores requires complete absence of oxygen, temperatures ranging from 60 to $97^{\circ} \mathrm{F}$, a source of animal protein, and a pH ranging from 5.7 to 8.0. 


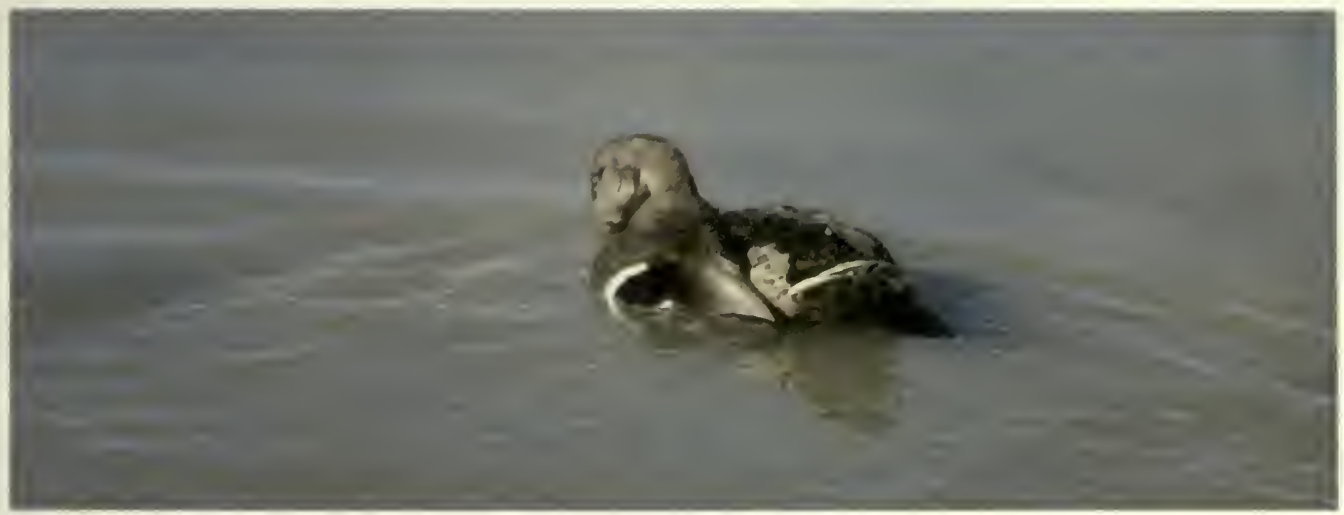

Limberneck occurs at an advanced stage of botulism poisoning.

\section{The Botulism Cycle}

Favorable environmental conditions occur in the tissues of decaying animal and insect carcasses. The decomposition process uses up all available oxygen in the carcass, creating anaerobic conditions. Bacterial spores ingested during the life of the animal germinate after death. As the bacteria multiply and die, toxin is released.

Outbreaks of avian botulism occur when the toxin is taken in by birds. The die-off may begin as birds feed directly on invertebrate carcasses that contain the toxin, or as a result of feeding on live maggots of flesh-flies and blowflies. Flies lay their eggs on dead vertebrates, and the resulting maggots store botulinal toxin in their bodies as they consume the carcass. More than 5,000 maggots can be produced by a single bird carcass; consumption of just two to five toxin-bearing maggots is often enough to kill a duck! 


\section{Cycle of Avian Botulism}

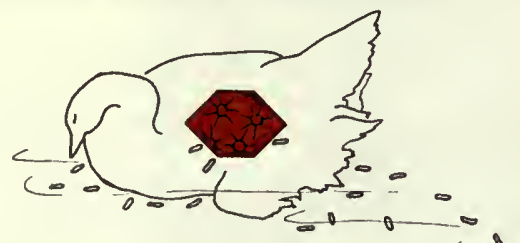

Toxin production takes place in decaying animal carcasses

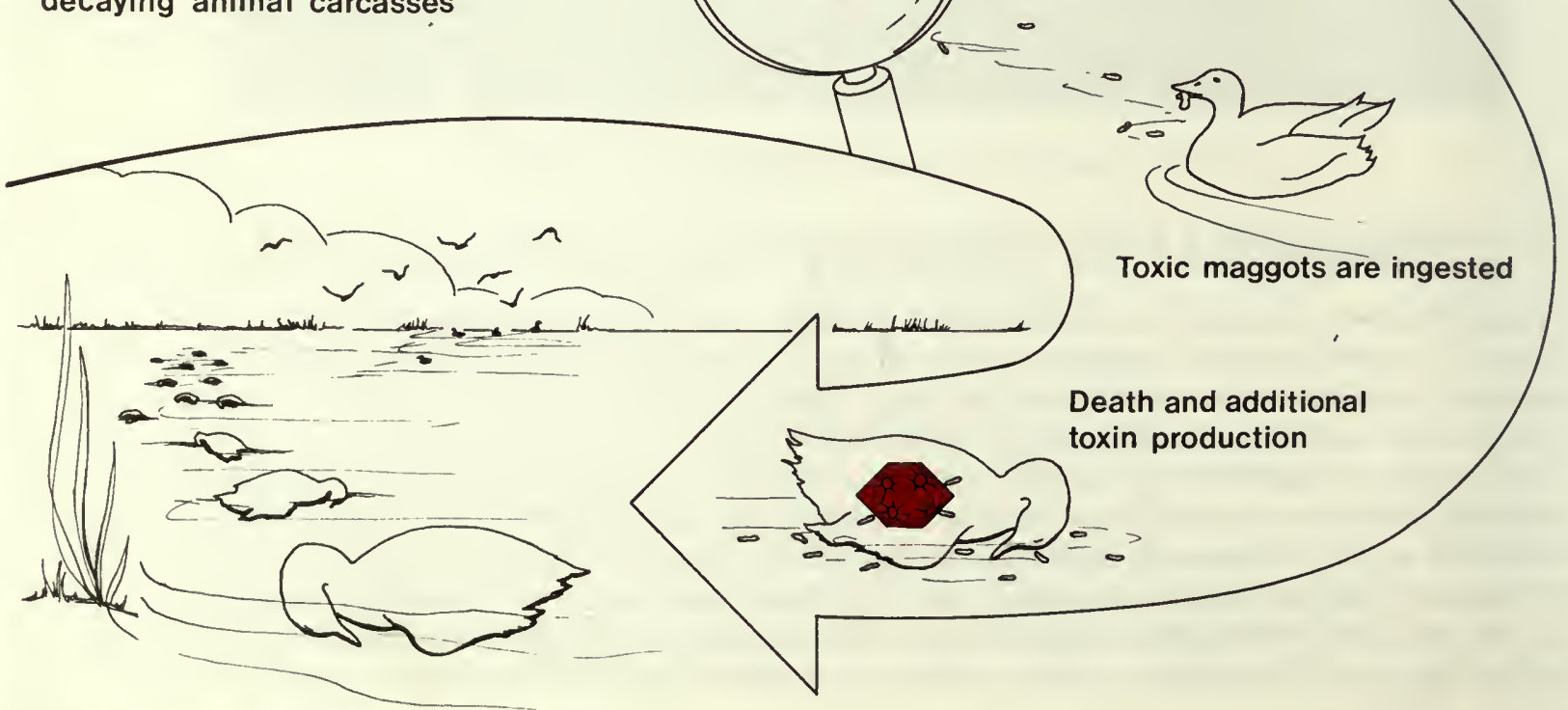

Cycle accelerates-major die-off occurs 


\section{CAN BOTULISM EPIDEMICS BE PREVENTED?}

Three factors contributing to the development of epidemics are: lowered water levels during hot summer months, an abundance of flies, and animal carcasses for toxin production. Disease prevention efforts, therefore, should focus on these factors.

\section{Control of Water Levels}

Areas managed for shorebirds and waterfowl should not be reflooded in summer if the areas have been dry for a prolonged period of time. Rather, reflooding to accommodate the fall migration should take place when temperatures become cooler in early fall. Similarly, summer drawdowns of impounded water should be avoided because that can result in fish kills. Fish carcasses also provide a suitable medium for bacterial growth. Some management programs require water drawdowns; for example, to provide a feather edge of habitat for foraging shorebirds. In these cases, botulism prevention programs must focus on stabilizing water levels to maintain a minimally fluctuating feather edge.

\section{Carcass Removal}

Prompt removal of any carcasses that may occur is essential for preventing development of die-offs during periods with hot daytime and warm nighttime ambient temperatures. For example, when control of undesirable fish species such as carp occurs on areas used by birds, managers need to dispose properly of fish carcasses. All animal carcasses should be removed and burned or buried deeply. This will eliminate the major source of toxin production and maggot development. If these steps are not taken, toxin materials may build up 
rapidly, increasing losses and adding more toxin to the environment as carcasses decompose and more bacteria are produced. Toxin formed in these carcasses is quite stable and can serve as the source of outbreaks for many months.

\section{CAN SICK BIRDS BE TREATED?}

Studies at the Bear River Migratory Bird Refuge in Utah have demonstrated that most birds suffering from botulism can be saved. Providing fresh water and shade may be all that is required to save birds in early stages of the disease. Injecting birds with antitoxin can result in recovery of over 75 percent of the birds. However, capturing sick birds and treating them with antitoxin is costly. This treatment is generally reserved for endangered species.

In dealing with avian botulism, the emphasis should be on prevention and control of outbreaks, rather than treatment of poisoned birds. Identifying possible cases of avian botulism at early stages is the key to effective control. Public awareness of the conditions that lead to avian botulism, and prompt corrective action, can greatly reduce the epidemics which now claim hundreds of thousands of avian lives each year. We encourage anyone observing avian mortality suggestive of an avian botulism problem to promptly report it to state and federal authorities. 


\section{REFERENCES}

Jensen, W. I. and J. P. Allen. 1960. "A Possible Relationship Between Aquatic Invertebrates and Avian Botulism." Transactions of the North American Wildlife and Natural Resources Conference. Volume 25, pages 171-180.

Rosen, M. N. 1971. "Botulism." Pages 100-117 in: J. W. Davis, R. C. Anderson, L. Karstad, and D. O. Trainer (eds.). Infectious and Parasitic Diseases of Wild Birds. Iowa State University Press, Ames, Iowa. 344 pages.

Smith, L. D. 1977. Botulism: the organism, its toxins, the disease. Charles C. Thomas, Springfield, Illinois. 263 pages. 



\section{DEDICATION}

Wildlife disease research in what is now the U.S. Fish and Wildlife Service originated in the early 1900 's with investigations within what was then the Bureau of Biological Survey. Losses of millions of birds to an unknown malady, later determined to be avian botulism, stimulated the beginning of concentrated scientific research involving disease problems in migratory birds.

Much of what is currently known about this disease in migratory birds resulted from research conducted at the Fish and Wildlife Service's Bear River Research Station in Brigham City, Utah. These research efforts span 30 years of time, from the early 1940 's to the mid-1970's. For approximately 25 years of that time, Dr. Wayne I. Jensen, Microbiologist-inCharge of that station, dedicated his efforts toward developing an understanding of avian botulism that could eventually lead to prevention and control of this disease.

We dedicate this publication to Dr. Jensen in recognition of his personal dedication, professionalism, high scientific standards, and personal sacrifices in carrying out his research efforts. He has inspired our own scientific development and investigative efforts and is truly an outstanding individual. 
